\title{
Co relating NIFTY 50 Index Trend's impact on NSE's Sector based Indices Growth Momentum in Post COVID-19 led Indian Economy with Special reference to NIFTY Bank, NIFTY Consumer Durables, NIFTY IT and NIFTY Pharma Indices using Arithmetic Modelling
}

R.Amuthan, Associate Professor, Department of Management Studies, Karunya Institute of technology and Science, Coimbatore

Article History: Received: 10 November 2020; Revised 12 January 2021 Accepted: 27 January 2021; Published online: 5 April 2021

\begin{abstract}
The NIFTY 50 is the flagship index on the National Stock Exchange of India Ltd. (NSE). The Index tracks the behavior of a portfolio of blue chip companies, the largest and most liquid Indian securities. It includes 50 of the approximately 1600 companies traded (listed \& traded and not listed but permitted to trade) on NSE, captures approximately $65 \%$ of its float-adjusted market capitalization and is a true reflection of the Indian stock market. This study probed in to the correlation between NIFTY 50 and NIFTY Bank, NIFTY 50 and NIFTY Consumer Durables, NIFTY 50 and NIFTY IT and NIFTY 50 and NIFTY Pharma Indices
\end{abstract}

Keywords: Sectorial Indices, Coinciding Trend, Prediction, Upswing, Downswing

\section{Statement of Problem:}

Stock Market has been volatile at the highest order since its inception. Due to it, Investors are at cross roads about the enjoyment of returns on Investment particularly in sector based indices. Some sector indices are always better than NIFTY 50 and some indices are always lower than NIFTY 50. Hence, it seems to be unavoidable that a investor should read the trend lines of all the indices on regular basis. During most of time, the outlooks of NIFTY 50 reflect on sector based indices both directly and indirectly.

\subsection{Objectives of the Study:}

* To find out the Coinciding Trend between NIFTY 50 and Sector based Indices, To forecast the Index points trend To find out the Good and Bad Performing Sector Indices.

\subsubsection{Design of the Study:}

This study is of analytical in nature due to the study of past days trading from May $1^{\text {st }} 2020$ to Dec.31, 2020. The trend will throw some light on how is every day NIFTY points created impact on sector based indices namely NIFTY Bank Index, NIFTY Consumer Durable Index, NIFTY IT Index, and NIFTY Pharma. It has been observed that how NIFTY 50 points have got regressed with Sector Indices points and with the help of Moving average, the future points are predicted and if the average return of Sector indices return is more than the returns of NIFTY 50, it is good for Sector Indices and If it is vice versa, then it will be good for NIFTY 50.

\subsubsection{Tools used for Analysis:}

Multiple Regression Analysis and Correlation Analysis are used to keep track of co-relating trend between NIFTY 50 and Sector Indices particularly NIFTY Bank, NIFTY Consumer Durables, NIFTY IT and NIFTY Pharma Sectors. Past Price behaviour and Current Price Behaviour and there by finding out strong performance Indices and in order to predict the trend, the forecasting was done for the month of March 2021 and April 2021 by means of applying E-Views-7 software. 


\section{Results and Discussion:}

Stock Market results is the viral effect of positive or negative news, Business Momentum, Government Policy, pandemic related Incidences, positive or negative actions of Foreign Portfolio Investors. In this Context, this study encompasses the movements of 4 indices and bench mark S\&P CNX NIFTY 50. The impact of NIFTY 50 on other indices are clearly introspected. The trading activities of NIFTY 50 and other form indices were taken in to account from October 2019 to January 2021. Nevertheless Indian Economy experienced abounding shocks due to COVID-19 induced pandemic and Since March 2020, unpreceded negatives on all economic metrics namely GDP, IIP, and National Income as never before, Indian Stock Market experienced only cracker of crack for bull in the trend. The number of times stock market received upswing are far more than downswings. In the downstream, Indian Stock Market has proved that both NSE and BSE are powerful money making Investment houses. The Correlation Technique was devised to look in to the co relation between S\&P CNX NIFTY 50 and Bank NIFTY; S\&P CNX NIFTY 50 and NIFTY IT; S\&P CNX NIFTY 50 and NIFTY Pharma and S\&P CNX NIFTY 50 and NIFTY Consumer Durables. In the end, the forecasting has been worked out from February 2021 to May 2021 through the application of E-Views software and its trend has been observed and with the help of forecasting, no of times for Upswings and No of times for downswing are analysed.

Table -1 showing Monthly Average NSE Indices points

\begin{tabular}{|l|l|l|l|l|l|l|}
\hline S.No. & Months & $\begin{array}{l}\text { S\&P CNX } \\
\text { NIFTY 50 }\end{array}$ & Bank NIFTY & NIFTY IT & $\begin{array}{l}\text { NIFTY } \\
\text { PHARMA }\end{array}$ & $\begin{array}{l}\text { NIFTY } \\
\text { Consumer } \\
\text { Durables }\end{array}$ \\
\hline 1 & Oct-19 & $\mathbf{1 1 8 7 7 . 4 5}$ & $\mathbf{3 0 0 6 6 . 0 0}$ & $\mathbf{1 5 5 5 9 . 4 0}$ & $\mathbf{7 8 7 8 . 1 5}$ & $\mathbf{1 4 4 5 0 . 3 5}$ \\
\hline 2 & Nov-19 & $\mathbf{1 2 0 5 6 . 0 5}$ & $\mathbf{3 1 9 4 6 . 1 0}$ & $\mathbf{1 4 9 9 8 . 0 5}$ & $\mathbf{8 1 8 9 . 7 5}$ & $\mathbf{1 6 7 8 0 . 1 0}$ \\
\hline 3 & Dec-19 & $\mathbf{1 2 1 6 8 . 4 5}$ & $\mathbf{3 2 1 6 1 . 6 5}$ & $\mathbf{1 5 6 5 2 . 4 0}$ & $\mathbf{8 0 4 0 . 1 5}$ & $\mathbf{1 7 2 5 0 . 2 4}$ \\
\hline 4 & Jan-20 & $\mathbf{1 1 9 6 2 . 1 0}$ & $\mathbf{3 0 8 3 3 . 6 0}$ & $\mathbf{1 6 1 4 4 . 1 5}$ & $\mathbf{8 1 3 8 . 6 0}$ & $\mathbf{1 8 5 5 0 . 6 1}$ \\
\hline $\mathbf{5}$ & Feb-20 & $\mathbf{1 3 9 8 1 . 7 5}$ & $\mathbf{2 9 1 4 7 . 1 5}$ & $\mathbf{1 5 2 1 2 . 9 5}$ & $\mathbf{7 5 7 6 . 5 0}$ & $\mathbf{1 8 6 7 0 . 8 5}$ \\
\hline 6 & March-20 & $\mathbf{1 2 9 6 8 . 9 5}$ & $\mathbf{1 9 1 4 4 . 0 0}$ & $\mathbf{1 2 7 6 3 . 6 5}$ & $\mathbf{7 1 7 6 . 5 0}$ & $\mathbf{1 9 3 6 2 . 9 6}$ \\
\hline $\mathbf{7}$ & April-20 & $\mathbf{1 1 6 4 2 . 4 0}$ & $\mathbf{2 1 5 3 4 . 5 0}$ & $\mathbf{1 4 1 0 8 . 4 0}$ & $\mathbf{9 3 2 7 . 1 0}$ & $\mathbf{2 0 5 2 5 . 3 9}$ \\
\hline $\mathbf{8}$ & May-20 & $\mathbf{1 1 2 4 7 . 5 5}$ & $\mathbf{1 9 2 9 7 . 2 5}$ & $\mathbf{1 4 0 1 0 . 5 0}$ & $\mathbf{9 7 6 8 . 6 0}$ & $\mathbf{1 8 9 6 6 . 5 4}$ \\
\hline $\mathbf{9}$ & June-20 & $\mathbf{1 1 3 8 7 . 5 0}$ & $\mathbf{2 1 3 7 0 . 1 5}$ & $\mathbf{1 4 7 5 4 . 3 0}$ & $\mathbf{9 9 8 5 . 1 5}$ & $\mathbf{2 0 3 3 8 . 2 0}$ \\
\hline 10 & July-20 & $\mathbf{1 1 2 4 7 . 5 5}$ & $\mathbf{2 1 6 4 0 . 0 5}$ & $\mathbf{1 8 0 7 1 . 8 5}$ & $\mathbf{1 1 1 4 8 . 9 0}$ & $\mathbf{2 1 4 7 9 . 2 4}$ \\
\hline 11 & Aug-20 & $\mathbf{1 1 6 4 2 . 4 0}$ & $\mathbf{2 3 7 5 4 . 3 5}$ & $\mathbf{1 7 9 2 8 . 8 5}$ & $\mathbf{1 1 0 7 9 . 8 0}$ & $\mathbf{2 2 7 5 8 . 4 8}$ \\
\hline 12 & Sep-20 & $\mathbf{1 2 9 6 8 . 9 5}$ & $\mathbf{2 1 4 5 1 . 8 0}$ & $\mathbf{1 9 9 5 1 . 3 5}$ & $\mathbf{1 1 7 7 2 . 8 5}$ & $\mathbf{2 4 2 7 8 . 0 9}$ \\
\hline 13 & Oct-20 & $\mathbf{1 3 9 8 1 . 7 5}$ & $\mathbf{2 3 8 0 0 . 9 0}$ & $\mathbf{2 0 9 1 6 . 8 5}$ & $\mathbf{1 1 2 4 3 . 7 5}$ & $\mathbf{2 4 0 7 6 . 2 8}$ \\
\hline 14 & Nov-20 & $\mathbf{1 4 5 9 0 . 3 5}$ & $\mathbf{2 9 6 0 9 . 0 5}$ & $\mathbf{2 0 9 1 6 . 8 5}$ & $\mathbf{1 1 8 3 9 . 1 5}$ & $\mathbf{2 4 0 0 2 . 0 0}$ \\
\hline 15 & Dec.-20 & $\mathbf{1 2 1 6 8 . 0 5}$ & $\mathbf{3 1 2 6 4 . 0 5}$ & $\mathbf{2 4 2 5 1 . 3 5}$ & $\mathbf{1 2 9 1 5 . 9 0}$ & $\mathbf{3 0 3 9 3 . 5 0}$ \\
\hline 16 & Jan-21 & $\mathbf{1 4 5 9 0 . 3 5}$ & $\mathbf{3 1 9 9 8 . 9 0}$ & $\mathbf{2 7 0 2 7 . 7 0}$ & $\mathbf{1 3 4 1 2 . 3 5}$ & $\mathbf{3 0 8 3 1 . 8 6}$ \\
\hline 17 & Feb-21 & $\mathbf{1 5 2 0 8 . 9 0}$ & $\mathbf{3 6 9 1 0 . 9 5}$ & $\mathbf{2 5 2 8 2 . 9 5}$ & $\mathbf{1 2 5 8 4 . 3 5}$ & $\mathbf{3 3 5 1 9 . 5 5}$ \\
\hline 18 & $\begin{array}{l}\text { March- } \\
\mathbf{2 1}(\text { Predicted) }\end{array}$ & $\mathbf{1 3 0 3 2 . 8 8}$ & $\mathbf{2 9 2 5 1 . 4 8}$ & $\mathbf{2 5 8 4 5 . 9 7}$ & $\mathbf{1 3 0 4 4 . 6 4}$ & $\mathbf{3 3 8 6 9 . 5 0}$ \\
\hline 19 & $\begin{array}{l}\text { April- } \\
\mathbf{2 1}(\text { Predicted) }\end{array}$ & $\mathbf{1 3 0 3 2 . 9 3}$ & $\mathbf{2 9 2 4 3 . 3 9}$ & $\mathbf{2 6 4 3 4 . 2 7}$ & $\mathbf{1 3 2 9 7 . 8 0}$ & $\mathbf{3 4 9 8 3 . 3 1}$ \\
\hline 20 & $\begin{array}{l}\text { ADF } \text { Test-p- } \\
\text { value }\end{array}$ & $\mathbf{0 . 0 0}$ & $\mathbf{0 . 0 3}$ & $\mathbf{0 . 0 2}$ & $\mathbf{0 . 0 1}$ & $\mathbf{0 . 0 0}$ \\
\hline
\end{tabular}

By the use of E-Views-7 software, the index points are predicted for both March 2021 and April 2021. There is the witness of market correction taking place in the month of March and April 2021. Due to the counter balancing measures being taken by Government of India to shrug off COVID-19 impacts, there was massive bull trend took place during Feb-2021 and March 2021. When the history of points read out, it was understandable that Jan and February euphoria are not continued during March and April 2021.In the case of CNX Nifty, it was reduced from 15208.90 points to 13032.88 points, in the case of Bank Nifty, the points were down from 32910.95 points to 29251.48 points, in the case of Nifty IT, the increasing trend 
has been continued, it is increased from 25282.95 points to 25845.97 points, with respect to Nifty Pharma, it is increased from 12584.35 points to 13044.64 and with respect to Nifty Consumer Durables, it is increased from 33519.55 points to 33869.50 points. The above mentioned results are statistically significant as $\mathrm{p}$ values are less than 0.05 .

Table -2 showing Model fit Summary

\begin{tabular}{|l|l|l|l|l|l|l|l|l|l|}
\hline Model & $\mathbf{R}$ & $\begin{array}{l}\text { R } \\
\text { Square }\end{array}$ & $\begin{array}{l}\text { Adjustable } \\
\text { R-Square }\end{array}$ & $\begin{array}{l}\text { Std } \\
\text { deviation } \\
\text { of } \\
\text { estimated }\end{array}$ & $\begin{array}{l}\text { R- } \\
\text { Square } \\
\text { Change }\end{array}$ & $\begin{array}{l}\text { F- } \\
\text { Change }\end{array}$ & df1 & df2 & $\begin{array}{l}\text { p- } \\
\text { value }\end{array}$ \\
\hline & $\mathbf{0 . 7 8 7}$ & $\mathbf{0 . 6 1 9}$ & $\mathbf{0 . 4 9 2}$ & $\mathbf{9 2 9 . 9 6}$ & $\mathbf{0 . 6 1 9}$ & 4.877 & 4 & 12 & $\mathbf{0 . 0 1 4}$ \\
\hline
\end{tabular}

Table-3 showing Anova Results

\begin{tabular}{|l|l|l|l|l|l|}
\hline Model & $\begin{array}{l}\text { Sum of } \\
\text { Squares }\end{array}$ & $\begin{array}{l}\text { Dean } \\
\text { Square }\end{array}$ & F & Sig. \\
\hline Regression & $\mathbf{1 6 8 7 1 6 3 0 . 9 7}$ & 4 & $\mathbf{4 2 1 7 9 0 7 . 4 2}$ & 4.377 & $\mathbf{0 . 0 1 4}$ \\
\hline Residual & $\mathbf{1 0 3 7 7 8 3 3 . 5 3}$ & $\mathbf{1 2}$ & $\mathbf{8 6 4 8 1 9 . 4 6 1}$ & & \\
\hline Total & $\mathbf{2 7 , 2 4 9 , 4 6 3}$ & & & & \\
\hline
\end{tabular}

a. Dependent Variable: CNX Nifty 50

b. Predictors( Constant), Bank Nifty, Nifty IT, Nifty Pharma and Nifty Consumer Durable

Interpretation regarding ANOVA Values:

The ANOVA table gives the details regarding the significance of the regression model developed above. The F-Value of 4.377 along with $\mathrm{P}<0,014$, It is concluded that the regression is statistically significant. The Mean Square is got by dividing sum of squares by degrees of freedom (df). Regression value explains significantly moderately more variance $(61.9 \%)$ than the residual error $(38.08 \%)$

Table-4 Co-efficient values

\begin{tabular}{|c|c|c|c|c|c|c|c|}
\hline Model & B & $\begin{array}{l}\text { Co- } \\
\text { efficient- } \\
\text { standard } \\
\text { Error }\end{array}$ & $\begin{array}{l}\text { Standard Co-efficient } \\
\text { Beta }\end{array}$ & $\begin{array}{l}\text { t- } \\
\text { value }\end{array}$ & Sig. & $\begin{array}{l}\text { Co-Linearity } \\
\text { tolerance }\end{array}$ & VIF \\
\hline (Constant) & 11933.43 & 2216.13 & - & 5.383 & 0.000 & -0020 & - \\
\hline $\begin{array}{l}\text { Bank } \\
\text { Nifty } \\
\end{array}$ & $-\mathbf{0 . 0 5 7}$ & 0.077 & -0.241 & 0.737 & 0.475 & 0.296 & $\mathbf{3 . 3 7 5}$ \\
\hline Nifty IT & 0.449 & 0.236 & 1.476 & 1.902 & 0.081 & 0.053 & 18.984 \\
\hline $\begin{array}{l}\text { Nifty } \\
\text { Pharma } \\
\end{array}$ & -0.863 & 0.386 & -1.350 & 2.234 & 0.045 & 0.087 & 11.498 \\
\hline $\begin{array}{l}\text { Nifty } \\
\text { Consumer } \\
\text { Durable }\end{array}$ & 0.131 & 0.119 & 0.530 & 1.100 & 0.293 & 0.136 & 7.328 \\
\hline
\end{tabular}

Dependent Variable: CNX Nifty

Source: SPSS Software

Interpretation regarding Tolerance Value and VIF Value. 


\begin{abstract}
The tolerance value for a particular independent variable in a particular is $1-\mathrm{R}$ square where the R-square is obtained using that independent variable as dependent variable and all other variables in the regression equation as independent. As a general rule of thumb, a tolerance value below 0.1 indicates a series multicollinearity problem. In the case of Variance Inflation Factor (VIF), this is just the reciprocal of the tolerance statistic. It is defined as 1 divided by tolerance value of 0.1 and above, there is a serious multicollinearity problem. With respect to this study, Co-linearity tolerance is above 0.10 against all indices namely Bank Nifty(0.296), Nifty IT(0.053), Nifty Pharma(0.087) and Nifty Consumer Durable is 0.136 ). Hence Co-linearity problem does not exist in this study. Regression result is significant as it has the $\mathrm{p}$ value of only 0.014 . Now CNX NIFTY CNX Index $=11933$ 0.057(Bank Nifty)+0.449(Nifty IT)-0.863(NIFTY Pharma)+0.131(Nifty Consumer Durable). From this equation, it is made known that Nifty IT and Nifty Consumer Durable are hugely influencing or co-relating the increase or decrease of CNK Nifty 50.
\end{abstract}

\title{
Variance Inflation Factor Index (VIF)
}

This is just the reciprocal of the tolerance statistic. It is defined as 1 divided by tolerance value. VIF is greater than or equal to 1. A VIF of greater than 5 generally indicates evidence of Multicollinearity. From the reading of Table-4, the association or correlation among Nifty IT, Nifty Pharma and Nifty Consumer Durables are very thick as their VIF values are Nifty IT is 18.984 , Nifty Pharma is 11.498 and Nifty Consumer Durable is 7.328 .

Table -6 Showing Correlation Results of NIFTY INDICES

\begin{tabular}{|l|l|l|l|l|l|}
\hline S.No. & $\begin{array}{l}\text { S\&P CNX } \\
\text { NIFTY 50 }\end{array}$ & Bank NIFTY & NIFTY IT & $\begin{array}{l}\text { NIFTY } \\
\text { PHARMA }\end{array}$ & $\begin{array}{l}\text { NIFTY } \\
\text { Consumer } \\
\text { Durables }\end{array}$ \\
\hline $\begin{array}{l}\text { S\&P CNX } \\
\text { NIFTY 50 }\end{array}$ & 1.00 & $\mathbf{0 . 1 7 7 ( S i g . 0 . 5 0 )}$ & $\mathbf{0 . 5 4 6 ( S i g . 0 . 0 2 9 )}$ & $\mathbf{0 . 3 2 5 ( S i g . 0 . 2 2 0 )}$ & 0.446(Sig.0.080) \\
\hline
\end{tabular}

Source: SPSS Software

\section{Interpretation:}

Results from SPSS Software stating that both NIFTY IT and NIFTY Consumer Durables are co relating with the trend of S\&P CNX NIFTY 50 which is in the values of 0.546 for NIFTY IT and 0.446 for NIFTY Consumer Durables. Bank NIFTY and NIFTY Pharma were against the Bench Mark Index. Both indices were found to be more momentum oriented. Whenever the good news are prevailing, these stocks are on the rise. This result is just reflecting the values arrived in Table4.

Table-7 Good and Bad Performing Sectorial Indices

\begin{tabular}{|l|l|l|l|l|}
\hline S.No. & $\begin{array}{l}\text { Bank } \\
\text { NIFTY(2) }\end{array}$ & NIFTY IT(3) & $\begin{array}{l}\text { NIFTY- } \\
\text { Pharma(2) }\end{array}$ & $\begin{array}{l}\text { NIFTY- } \\
\text { Consumer } \\
\text { Durables(1) }\end{array}$ \\
\hline $\begin{array}{l}\text { Upswing(Increase } \\
\text { in Points) }\end{array}$ & 10 & 9 & 10 & 12 \\
\hline $\begin{array}{l}\text { Down } \\
\text { swing(Increase in } \\
\text { Points) }\end{array}$ & 4 & 5 & 4 & 2 \\
\hline
\end{tabular}

Interpretation:

From the results of Upswings and Downswings, it is pretty much understandable that all the indices have performed well since Oct.2019 as there are more upswings than downswings. Among the best ones, NIFTY Consumer Durable is ranked No 1 as it has got $86 \% \%$; NIFTY Pharma and Bank NIFTY had been ranked No.3 as both of them have got $71 \%$ and NIFTY IT had been appreciated by $64 \%$. 


\subsection{Key Findings:}

I. Co-inciding trend used to be exist in NIFTY IT and NIFTY Consumer Durables due to high correlation or high Co-linearity with CNX Nifty 50 as it is due to high correlation values -0.546 and 0.445 for both NIFTY IT and NIFTY Consumer Durables respectively.

II. With respect to this study, Co-linearity tolerance is above 0.10 against all indices namely Bank Nifty(0.296), Nifty IT(0.053), Nifty Pharma(0.087) and Nifty Consumer Durable is 0.136). Hence Colinearity problem does not exist in this study. Regression result is significant as it has the $\mathrm{p}$ value of only 0.014. Now CNX NIFTY CNX Index = 11933-0.057(Bank Nifty) +0.449 (Nifty IT)-0.863(NIFTY Pharma)+0.131(Nifty Consumer Durable). From this equation, it is made known that Nifty IT and Nifty Consumer Durable are hugely influencing or co-relating the increase or decrease of CNK Nifty 50.

III. With respect to performance, NIFTY consumer Durables had proved that it is the best index as it was witnessed frequent Upswings (86\%) for the past 10 months from October 2019 onwards.

IV. The association or correlation or collinearity effect among Nifty IT, Nifty Pharma and Nifty Consumer Durables are very thick as their VIF values are Nifty IT is 18.984 , Nifty Pharma is 11.498 and Nifty Consumer Durable is 7.328. of these indices, Nifty IT and Nifty Consumer durables index points are hugely impacted due to the movements of benchmark Index-CNX Nifty 50

\section{Conclusion:}

Since the start of Covid-19 led pandemic, Indian Stock Market is turned around to bullish momentum during most of trading days after huge losses in 2019. NSE's Nifty indices are all equally performing well in delivering returns to the investors. S\&P CNX Nifty 50 has been the benchmark index in terms of conferring stable returns. Of the total NSE indices, Bank Nifty, Nifty IT, Nifty Pharma and Nifty Consumer Durables are used to be the active indexes in terms of trading. As a result of analyzing all these indexes in this study, it is concluded that Nifty IT and Nifty Consumer Durables are hugely influenced by S\&P CNX Nifty 50 movements. Their Correlation values are 0.546 and 0.446 respectively. S\&P CNX Nifty has got least influence on Bank Nifty and Nifty Pharma as they are most influenced by Industry movements and good news across products, business and markets.

\section{References:}

[1]. Yang, S. Y., Song, Q., Mo, S. Y., Datta, K., \& Deane, A. (2015). The impact of abnormal news sentiment on financial markets, Available at SSRN 2597247.

[2]. Kalyani, J., Bharathi, P., \& Jyothi, P. (2016). Stock trend prediction using news sentiment analysis at Xiv: 1607.01958.

[3]. Masry, M. (2017). The impact of technical analysis on stock returns in an emerging capital markets (ECM's) country: Theoretical and Empirical Study. International Journal of Economics and Finance,9(3), 91-107.

[4]. Baker, M., \& Wurgler, J. (2007). Investor sentiment in the stock market.Journal of economic perspectives,21(2), 129-152.

[5]. Annaert, J., Van Osselaer, S., and Verstraete,B. (2009): Performance Evaluation of Portfolio Insurance Strategies Using StochasticDominance Criteria, in Journal of Banking and Finance, Vol. 33,pp. 272-280.

[6]. .Arnott, R.D., and Bernstein P.I., (2002): What Risk Premium "Normal"? in Financial AnalystsJournal, Vol.58,pp. 64-85.3.

[7]. Basak, S. (1995): A General Equilibrium Model of Portfolio Insurance, Review of Financial Studies 8(4), 105910904.

[8]. Benninga, S. and Blume, M. (1985): On the Optimality of Portfolio Insurance, Journal of Finance 51, 1573-1610.5.

[9]. An Introduction to Bootstrap, NY: Chapman Hall/CCRC,1998.13.El Karoui, N., Jeamblane, m. and Lacoste, V. (2005), Optimal Portfolio Management with American Capital Guarantee, Journal of Economic Dynamics and Control 29, 449-468.

[10]..Eling, M., and Schuhmacher, F. (2007): Does the Choice of Performance Measure Influence the Evaluation of Hedge Funds?, in Journal of Banking and Finance, Vol. 31, pp. 2632-2647.15.

[11].Engle, R.(1982): Autoregressive Conditional Heteroscedasticity with Estimation of the Variance of United Kingdom Inflation, in Econometrica, Vol. 50, pp. 987-1007. 
[12].Estep, T., and Kritzman, M. (1988): TIPP: Insurance without complexity, in The Journal of Portfolio Management. Vol. 14, pp. 38-42.17.

[13].Fama, E.F., and French, K. (2002)The Equity Premium, in The Journal of Finance, Vol. 57, pp.637-659.

[14]. German H (1992) Portfolio Insurance and synthetic securities. Applied stochastic models and data analysis 8, pp. 179-188.

[15].Gomes, F. J.,2005, Portfolio Choice and Trading Volume with Loss-Averse Investors, Journal of Business 72, 675706.20 .

[16].Grossman, S., and S. J. Zhou Z (1996) Equilibrium analysis of portfolio incomplete markets: a note, Journal of Business 62, 473-476.21.

[17].Harlow n, W.V., and Rao, R. K. S. (1989): Asset Pricing in a generalized Mean-Lower Partial Moment Framework: Theory and Evidence in The Journal of Financial and Quantitative Analysis, Vol. 24, pp. 285-311.22

[18].https://www.moneycontrol.com/stocks/hist_index_result.php?indian_indices=9 